Jurnal Ilmiah Ibnu Sina, 6(1), Maret 2021, 108-115

p-ISSN: 2502-647X; e-ISSN: 2503-1902

\title{
STUDI PENGGUNAAN ANTIBIOTIK PASIEN PNEUMONIA ANAK DENGAN METODE DDD DAN DU $90 \%$
}

\author{
Farah Bidara $^{*}$, Mumfasiroh Saputri ${ }^{1}$, Dyah Aryani Perwitasari ${ }^{1}$, \\ Intan Fatah Kumara ${ }^{2}$, Muhammad Ardhani ${ }^{3}$ \\ ${ }^{1}$ Universitas Ahmad Dahlan \\ ${ }^{2}$ Rumah Sakit Mitra Paramedika Yogyakarta \\ ${ }^{3}$ Rumah Sakit Yadika Pondok Bambu Jakarta \\ *Email: farah.bidara12@gmail.com
}

Artikel diterima: 07 Desember 2020; Disetujui: 19 Februari 2021

DOI: https://doi.org/10.36387/jiis.v6i1.644

\begin{abstract}
ABSTRAK
Pneumonia merupakan salah satu penyakit infeksi saluran napas yang paling sering terjadi. Pengobatan pneumonia sebagian besar menggunakan antibiotik empiris spektrum luas yang rentan terjadi resistensi. Salah satu upaya untuk mengurangi resistensi antibiotik adalah menggunakan antibiotik dengan bijak yang dapat dilakukan dengan melakukan evaluasi penggunaan kuantitatif dan kualitatif antibiotik secara berkala. Tujuan penelitian adalah mengetahui kuantitas penggunaan dan jenis antibiotik yang digunakan pada pasien pneumonia anak bangsal rawat inap di Rumah Sakit Mitra Paramedika Yogyakarta (MPY) dan Yadika Pondok Bambu Jakarta (YPBJ) dengan metode DDD (Defined Daily Dose) dan DU (Drug Utiliy) 90\%. Penelitian ini merupakan penelitian deskriptif periode Juni 2017- April 2020 pada pasien anak yang berusia 1 - 18 tahun dengan diagnosa pneumonia. Pengambilan sampel dilakukan di Instalasi Rekam Medis. Data yang diambil adalah jenis antibiotik, regimen dosis, rute pemberian obat, lama terapi antibiotik (hari), dan lama rawat inap (hari) serta data demografi pasien (umur, jenis kelamin).Terdapat perbedaan pola penggunaan antibiotik antara Rumah Sakit. Perbadaan nilai DDD dan DU 90\% dapat disebabkan karena perbedaan standar terapi yang digunakan oleh dokter, resistensi antibiotik, perbedaan peta kuman dan formularium rumah sakit.
\end{abstract}

Kata kunci: Pneumonia, Anak, Antibiotik, Defined Daily Dose, DU 90\%

\section{ABSTRACT}

Pneumonia is one of the most common respiratory infections. The treatment of pneumonia mostly uses broad-spectrum empirical antibiotics that are susceptible to resistance. One of the efforts to reduce antibiotic resistance is to use antibiotics wisely which can be done by regularly evaluating the quantitative and qualitative use of antibiotics. The purpose of this study was to determine the quantity of consumption and the type of antibiotic used in patients pneumonia child inpatient ward at Hospital Mitra Paramedika Yogyakarta (MPY) and Yadika Pondok Bambu Jakarta (YPBJ) by DDD (Defined Daily Dose) and DU (Drug 
Jurnal Ilmiah Ibnu Sina, 6(1), Maret 2021, 108-115

p-ISSN: 2502-647X; e-ISSN: 2503-1902

utility) 90\%. This is a descriptive study period June 2017 - April 2020 in pediatric patients aged 1 - 18 years with a diagnosis of pneumonia. Sampling was performed at the Medical Record Installation. The Data taken were antibiotic type, dosage regimen, medication route, antibiotic duration (day), and hospital stay (day) as well as patient demographic data (age, type sex) .There are differences in the pattern of antibiotic use between hospitals. Comparison of DDD and DU $90 \%$ may be due to differences in standard of therapy used by physicians, antibiotic resistance, differences in germ maps and hospital formularies.

Keywords: Pneumonia, Children, Antibiotic, Defined Daily Dose, DU 90\%

\section{PENDAHULUAN}

Community

Pneumonia atau CAP merupakan salah satu penyebab utama morbiditas dan mortalitas dalam dunia kesehatan. (UNICEF, 2015). Pada tahun 2015 berkisar $16 \%$ dari 5,9 juta kematian pada pasien pneumonia adalah kasus pada anak-anak yang berusia dibawah 5 tahun (Walker, 2012). Pada tahun 2019 sebanyak 800.000 anak mengalami pneumonia khususnya usia dibawah 5 tahun (Black, 2013).

Dari data The United Nations Children's Fund (UNICEF) yang dilaporkan ditahun 2019, terdapat 19.000 kasus pneumonia yang merenggut anak Indonesia.

Pneumonia berawal dari infeksi akut jaringan parenkim alveoli yang disebabkan oleh virus, jamur ,bakteri, ,kerusakan fisik paru maupun pengaruh pajanan dari luar. Gejala pneumonia antara lain demam, sesak napas, sakit kepala, batuk berdahak dan menggigil (WHO, 2014). CAP merupakan jenis pneumonia yang didapat dari masyarakat atau terjadi dalam kurun waktu kurang dari 48 jam setelah pasien dirawat di rumah sakit. CAP merupakan jenis pneumonia yang paling sering terjadi (54,3\%) (IDAI, 2009).

Pneumonia dapat diakibatkan dari interaksi kompleks antara virulensi dan mikroorganisme yang dihirup pada saluran pernapasan bawah (PDPI, 2003). Regimen obat pada penyakit CAP adalah dengan penggunaan antibiotik. Pemilihan antibiotik harus berdasarkan etiologi bakteri dengan dosis yang efektif an durasi optimal. Pemilihan antibiotik empiris di Rumah Sakit dapat ditinjau berdasarkan peta kuman yang ada di tiap Rumah Sakit. Hal ini penting agar tidak terjadi keterlambatan 
Jurnal Ilmiah Ibnu Sina, 6(1), Maret 2021, 108-115

p-ISSN: 2502-647X; e-ISSN: 2503-1902

penanganan pada kasus pneumonia (UNICEF, 2018).

Dalam penilaian konsumsi antibiotik dapat menggunakan parameter seperti DDD dan DU 90\%. WHO menyatakan rata-rata DDD atau dosis harian standar obat yang digunakan pada $70 \mathrm{~kg}$ orang dewasa digunakan untuk indikasi yang paling umum (Torres, 2015). Sistem klasifikasi ATC merupakan kebutuhan sistem untuk membuat klasifikasi dan metrik standar untuk membandingkan konsumsi antibiotik antar fasilitas kesehatan, daerah, atau negara (Mountecatine, 2019).

Metode DDD hanya dapat digunakan pada antibiotik yang memiliki kode ATC. DDD merupakan unit pengukuran dan tidak harus sesuai dengan dosis harian yang diberikan kepada pasien. Dosis terapi untuk pasien bersifat individu, sehingga dapat berbeda dari DDD karena pemberian didasarkan pada karakteristik individu seperti usia, berat badan, perbedaan etnis, jenis dan tingkat keparahan penyakit, serta pertimbangan farmakokinetik (Bradley, 2011).
Metode Drug Utilization 90\% (DU 90\%) merupakan metode yang digunakan untuk menunjukkan pengelompokan obat yang masuk ke dalam 90\% penggunaan. Penilaian terhadap obat yang masuk ke dalam 90\% digunakan untuk pengendalian penggunaan obat dan perencanaan pengadaan obat (De, 2009).

Data pemanfaatan obat yang disajikan dalam DDD memberikan perkiraan konsumsi kasar dan bukan gambaran yang tepat tentang penggunaan aktual. Dengan menerapkan metode DDD, dimungkinkan untuk melakukan pemeriksaan perubahan penggunaan obat dari waktu ke waktu, sebagai acuan perbandingan internasional, mengikuti perubahan dalam penggunaan kelas obat dan mengevaluasi efek pengaturan dan efek intervensi pada pola peresepan (Bradley, 2011).

\section{METODE PENELITIAN}

Penelitian ini telah dikaji berdasarkan prinsip etik dari Komite Etik Yayasan Kartika Eka Paksi dengan nomor izin: Skep/084/KEPK/VIII/2020. 
Jenis penelitian ini adalah Instrumen penelitian/teknik deskriptif pada pasien anak dengan pengumpulan data sekunder didapat diagnosa CAP. Pengambilan sampel dari rekam medis pasien. Pada dilakukan di Instalasi Rekam Medis analisis kuantitatif menggunakan RS MPY dan YPBJ periode Juni metode DDD meliputi jenis 2017- April 2020. Klasifikasi usia antibiotik, regimen dosis, rute pada penelitian ini adalah $1-18$ tahun. Kriteria eksklusi adalah data Rekam Medis pasien tidak lengkap, pasien yang tidak mendapatkan terapi antibiotik, pasien pulang paksa dan meninggal sebelum dinyatakan sembuh, serta pasien yang meneruskan terapi antibiotik dari rumah sakit lain yang melakukan rujukan.

Metode pengambilan sampel yang digunakan adalah purposive sampling berdasarkan data rekam medis pasien anak dengan diagnosa CAP berdasarkan hasil pemeriksaan klinis dan rontgen toraks spesifik pneumonia sesuai yang tercantum di rekam medis serta pasien memperoleh terapi antibiotik empiris di bangsal rawat inap. Data yang diambil kemudian dianalisis menggunakan metode DDD dan DU $90 \%$.

Bahan yang digunakan pada penelitian adalah rekam medis pasien anak dengan diagnosa CAP. pemberian obat, lama terapi antibiotik (hari), dan lama rawat inap (hari) serta data demografi pasien (umur, jenis kelamin). Analisis data yang digunakan pada penelitian ini adalah mendeskripsikan data - data yang didapat dari rekam medis dan analisis kuantitatif dilakuskan dengan menghitung kuantitas penggunaan antibioik pada pasien CAP anak menggunakan metode DDD dan DU 90\%. Berikut rumus perhitungan penggunakan antibiotik dengan menggunakan metode DDD (Montecatine, 2019):

jumlah gram $A B$ yang digunakan oleh semua pasien Standar DDD WHO dalam gram

$\mathrm{X} \frac{100}{\text { Total hari rawat }}$

DU 90\% didapatkan dari penggunan antibiotik yang mencapai $90 \%$ di rumah sakit.

\section{HASIL DAN PEMBAHASAN}

Jumlah populasi yang didapat melalui data Rekam Medis dari kedua 
Jurnal Ilmiah Ibnu Sina, 6(1), Maret 2021, 108-115

p-ISSN: 2502-647X; e-ISSN: 2503-1902

rumah sakit adalah 129 pasien.

anak. Hasil perhitungan nila DU 90\%

Terdapat 2 pasien dengan kriteria menunjukkan bahwa jenis antibiotik eksklusi, sehingga total kriteria inklusi sebesar 127 pasien. Tabel 1 menampilkan data demografi pasien dari rumah sakit yang terdiri dari 68 pasien RS YPBJ dan 59 pasien dari RS MPY. Data hasil pengkajian penggunaan antibiotik kuantitatif di rawat inap pada kasus pneumonia anak dilakukan dengan menghitung DDD dan DU 90\%. Antibiotik yang digunakan pada RS YPBJ sebanyak 6 jenis. Semakin sedikit jenis antibiotik yang digunakan, menunjukkan dokter lebih selektif dalam peresepan antibiotik (Kusuma, 2016).

Hasil perhitungan menunjukkan bahwa nilai DU 90\% RS YPBJ berturut-turut dengan total DDD/hari rawat inap adalah Ceftriaxone sebesar 12.01 gr $(29,89 \%)$, Cefotaxime sebesar 11,28 gr $(28,08 \%)$, cefixime sebesar 9,18 gr $(22,85 \%)$, dan azitromicin 4,01 gr (9,99\%). RS MPY menggunakan sembilan jenis antibiotik dalam peresepan CAP pada anak.

Perhitungan DDD RS MPY menunjukkan 80,90 gr DDD/100 hari rawat inap untuk pasien pneumonia yang digunakan tertinggi berturutturut dengan total DDD/ hari rawat inap adalah Gentamycin sebesar 32,25 gr (39,86\%), Ampisilin sebesar 16,04 gr $(19,82 \%)$, Ceftriaxone sebesar 11,65 gr $(14,40 \%)$, dan Azitromisin sebesar 10,27 gr $(12,67 \%)$.

Tabel 1. Data Demografi Pasien RS

\begin{tabular}{lcc}
\multicolumn{3}{c}{ YPBJ dan MPY } \\
\hline $\begin{array}{l}\text { Karakteristik } \\
\text { Pasien }\end{array}$ & RS & RS MPY \\
Jenis Kelamin & & \\
$\quad$ Laki-laki & 28 & 20 \\
Perempuan & 40 & 39 \\
\hline Usia & & \\
2 sampai 6 Bulan & 2 & 0 \\
6 sampai 12 Bulan & 21 & 7 \\
1 sampai 4 Tahun & 35 & 33 \\
4 sampai 8 Tahun & 5 & 14 \\
8 sampai 15 Tahun & 4 & 4 \\
15 sampai 18 Tahun & 1 & 1 \\
\hline Lama Rawat Inap & & \\
1 hari & 1 & 0 \\
2 hari & 1 & 10 \\
3 hari & 27 & 20 \\
4 hari & 13 & 13 \\
$\geq 5$ hari & 26 & 16 \\
\hline Berat Badan Pasien & & \\
1-5 kg & 1 & 3 \\
5,1 - 10 kg & 33 & 29 \\
10,1 - 15 kg & 25 & 18 \\
15,1 - 20 kg & 3 & 5 \\
$\geq 20 \mathrm{~kg}$ & 6 & 4 \\
\hline
\end{tabular}

Terdapat perbedaan nilai yang signifikan dalam hasil perhitungan DDD dan DU 90\% pada kedua Rumah Sakit. DU 90\% RS YPBJ didominasi antibiotik golongan 
Jurnal Ilmiah Ibnu Sina, 6(1), Maret 2021, 108-115

p-ISSN: 2502-647X; e-ISSN: 2503-1902

sefalosporin generasi ketiga, terapi utama pada pengobatan CAP sementara RS MPY didominasi oleh anak dengan umur dibawah 1 tahun golongan penisilin dan (Mathur, 2016).

aminoglikosida. Penisilin dan aminoglikosida merupakan standar

Tabel 2. DDD dan DU 90\% RS YPBJ

\begin{tabular}{cccccc}
\hline $\begin{array}{c}\text { Jenis } \\
\text { Antibiotik }\end{array}$ & $\begin{array}{c}\text { Kode } \\
\text { ATC }\end{array}$ & $\begin{array}{c}\text { DDD Standar } \\
\text { WHO (gram) }\end{array}$ & $\begin{array}{c}\text { DDD total } \\
\text { (gram) }\end{array}$ & $\begin{array}{c}\text { DDD per 100 } \\
\text { hari ranap RS } \\
\text { (gram) }\end{array}$ & DU 90\% \\
\hline Ceftriaxon & J01DD04 & 2 & 32.42 & 12.01 & $29.89 \%^{*}$ \\
Cefotaxim & J01DD01 & 4 & 30.46 & 11.28 & $28.08 \%^{*}$ \\
Cefixim & J01DD08 & 0.4 & 24.78 & 9.18 & $22.85 \% *^{*}$ \\
Azitromicyn & J01FA10 & 0.3 & 10.84 & 4.01 & $9.99 \%^{*}$ \\
Gentamicyn & J01GB03 & 0.24 & 9.46 & 3.50 & $8.72 \%$ \\
Ceftazidim & J01DD02 & 4 & 0.50 & 0.19 & $0.46 \%$ \\
\hline & Total & & 108.46 & 40.17 & \\
\hline
\end{tabular}

*Antibiotik DU 90\%

Tabel 3. DDD dan DU 90\% RS YPBJ

\begin{tabular}{cccccc}
\hline $\begin{array}{c}\text { Jenis } \\
\text { Antibiotik }\end{array}$ & $\begin{array}{c}\text { Kode } \\
\text { ATC }\end{array}$ & $\begin{array}{c}\text { DDD Standar } \\
\text { WHO (gram) }\end{array}$ & $\begin{array}{c}\text { DDD total } \\
\text { (gram) }\end{array}$ & $\begin{array}{c}\text { DDD per 100 } \\
\text { hari ranap RS } \\
\text { (gram) }\end{array}$ & DU 90\% \\
\hline Gentamycin & J01GB03 & 0.24 & 72.89 & 32.25 & $39.86^{*}$ \\
Ampisilin & J01GB03 & 6.0 & 36.24 & 16.04 & $19.82^{*}$ \\
Ceftriaxone & J01DD04 & 2.0 & 26.32 & 11.65 & $14.40^{*}$ \\
Azitromisin & J01FA10 & 0.3 & 23.21 & 10.27 & $12.69^{*}$ \\
Cotrimoxazol & J01EA01 & 0.4 & 12.24 & 5.42 & 6.69 \\
Cefixime & J01DD08 & 0.4 & 5.58 & 2.47 & 3.05 \\
Cefotaxime & J01DD01 & 4.0 & 4.17 & 1.84 & 2.29 \\
Amoxicillin & J01CA04 & 3.0 & 1.70 & 0.75 & 0.94 \\
Cefadroxyl & J01CA04 & 1.5 & 0.48 & 0.21 & 0.26 \\
\hline \multicolumn{7}{c}{ Total } & & 182.83 & 80.9 & 4.17 \\
\hline
\end{tabular}

*Antibiotik DU 90\%

Pada penelitian yang lain, disebabkan perbedaan standar terapi efikasi ceftriaxone signifikan lebih yang digunakan oleh dokter, tinggi dibandingkan Penisilin pada resistensi antibiotik, perbedaan peta pasien CAP anak (Abid, 2020). Nilai kuman dan formularium rumah sakit.

DDD kedua rumah sakit secara umum Pada Tabel 2 antibiotik yang berbeda jauh dengan nilai DDD menduduki tingkat pertama sampai ke WHO. Perbedaan nilai DDD dan DU 90\% tiap rumah sakit dapat berbeda tiga yaitu antibiotik golongan sefalosporin generasi ketiga. 
Meskipun tidak mengesampingkan antibiotik dari golongan makrolida dan gentamisin sebagai lini pertama yang masih digunakan. Pemilihan antibiotic lini kedua ini sebagai predictor antibiotic apabila antibiotik lini pertama yaitu penisillin atau ampisillin gagal atau memburuknya status klinis pasien (Waqas, 2019).

\section{KESIMPULAN}

Hasil penelitian menunjukkan bahwa terdapat perbedaan penggunaan antibiotik antara kedua rumah sakit pada pasien CAP anak. Perbadaan nilai DDD dan DU 90\% dapat disebabkan karena perbedaan standar terapi yang digunakan oleh dokter, resistensi antibiotik, perbedaan peta kuman dan formularium rumah sakit.

\section{UCAPAN TERIMA KASIH}

Penulis mengucapkan banyak terima kasih kepada Kementrian Riset dan Teknologi Direktorat Jendral Pendidikan Tinggi atas pendanaan yang telah diberikan dengan nomor kontrak penelitian: PTM010/SKPP.TT/LPPM UAD/VI/2020

Tanggal 08 Juni 2020.

\section{DAFTAR PUSTAKA}

Abid, H., Rizwan, W., Naeem, I., (2020). Efficacy of amoxicillinclavulanic acid versus ceftriaxone in children hospitalized under 5 years of age with uncomplicated community acquired pneumonia. The Professional Medical Journal, 27(11), 23392344.

Black, R. E. (2013). Global burden of childhood pneumonia and diarrhoea. The Lancet, 381(9875), 1405-1416.

Bradley, J. S., Byington, C. L., Shah, S. S., Alverson, B.,. (2011). Executive summary: The management of communityacquired pneumonia in infants and children older than 3 months of age: Clinical practice guidelines by the pediatric infectious diseases society and the infectious diseases society of America. Clinical Infectious Diseases, 53(7), 617-630.

De WK, Bestehorn H, Steib-Bauert M, (2009) Comparison of defined versus recommended versus prescribed daily doses for measuring hospital antibiotic consumption. Infection.;37(4): 349-52.

IDAI. (2009). Pedoman pelayanan medis. Pedoman Pelayanan Medis, 58-61

Kusuma, A. M., Galistiani, G. F., Wijayanti, D. N., (2016). Artikel Penelitian Evaluasi Kuantitatif Penggunaan Antibiotik pada Pasien Caesarean Section di RSUD se- 
Jurnal Ilmiah Ibnu Sina, 6(1), Maret 2021, 108-115

p-ISSN: 2502-647X; e-ISSN: 2503-1902

Kabupaten Banyumas. Jurnal Farmasi Indonesia, 8(1), 327333.

Lassi, Z. S., Das, J. K., Haider, S. W., (2014). Systematic review on antibiotic therapy for pneumonia in children between 2 and 59 months of age. Archives of Disease in Childhood, 99(7), 687-693.

Mathur, S., Fuchs, A., Bielicki, J., (2016). Antibiotic Use for Community Acquired Pneumonia ( CAP ) in Neonates and Children: WHO Evidence Review, Pediatrics and International Child Health 38:S66-S75

Montecatine-Alonso, E., Gil-Navarro, M. V., Fernández-Llamazares, C. M., (2019). Antimicrobial defined daily dose adjusted by weight: a proposal for antibiotic consumption measurement in children. Enfermedades Infecciosas $Y$ Microbiologia Clinica, 37(5), 301-306.

Torres, A., Cillóniz, C., Ferrer, M., Gabarrús, A., (2015). Bacteraemia and antibioticresistant pathogens in community acquired pneumonia: Risk and prognosis. European Respiratory Journal, 45(5), 1353-1363.

UNICEF analysis produced in September 2019, based on WHO and Maternal and Child Epidemiology Estimation Group (MCEE) interim estimates and the United Nations Inter-agency Group for Child Mortality Estimation estimates for the year 2018.
UNICEF. Committing to Child Survival: A Promise Renewed Progress Report 2014. New York, NY: United Nations Children's Fund; 2015.

Walker, Fisher,. (2012). Pathophysiology of Community Acquired Pneumonia. 60(January).

Waqas, M. (2019). Comparative Efficacy of Ceftriaxone Versus Penicillin in the Treatment of Children with Severe Community-Acquired Pneumonia (CAP). Biomedical Journal of Scientific \& Technical Research, 14(4), 10817-10821

WHO. (2014). WHO methodology for a global programme on surveillance of antimicrobial consumption antimicronial consumption World Health Organization, 1-44 